\title{
Reflections on the Nature of Science and Human Ecology in Educational Practice
}

Evaldo Raymundo Dias da Silva, Ricardo José Rocha Amorim, Dinani Gomes Amorim

\section{ABSTRACT}

This paper initially seeks to systematize the foremost arguments presented by different authors to justify the importance of considering aspects of the Natural Sciences in teaching activities. From this opening framework and based on responses obtained in the application of the VNOS-C questionnaire (Views of Nature of Science, Form C), as well as the use of semistructured interviews, reports have been acquired explaining teaching aspects about the nature of sciences in the context of Secondary School. More specifically, under the eyes of teachers in the field of Biology, Physics and Chemistry, outlining some trends and perspectives in the schooling practice of teachers of Natural Sciences, concerning the possibility that they consider in their teaching activities some of the aspects of the nature of sciences and Human Ecology. As main results of this study, we found that the concerns of teachers go beyond the perspective of teaching Science, Technology and Society, as their concerns extend to broader educational issues, such as continued progression, the decrease in the number of classes in Natural Sciences and the role of the school in society.

Keywords:

Conceptions of Secondary School Teachers, Natural Sciences, Science in School Program, Human Ecology

\section{Introduction}

It is evident that, in recent years, there has been perceived an increase in the number of pronouncements that lay the role of education in an obligatory manner as a possibility of transforming the social condition of the subject. This perception is strictly linked to the concerns of social life that permeate other spheres of discussion, such as politics and economics that, in a certain way, legislate and attest to the spaces of human social production. Although debates related to Science and Technology have remained restricted for long periods to scientists, technologists, philosophers, and politicians, among other specialists in various fields, today it is increasingly necessary for Society, in addition to having access to information about the scientific-technological development, may be able to evaluate and make decisions about facts and consequences that may directly affect their lives (Santos, 1999; Praia \& Cachapuz, 2005).

The teacher's acceptance of the nature of sciences by has been identified as one of the essential aspects of scientific literacy, vital to the critical and responsible evaluation of policies, as well as the scientific and technological proposals. Lederman (2007) considers that, in a scientific and technologically advanced society, the citizen exercise and democracy will only be possible through the understanding of the scientific enterprise and its interactions with technology and culture.

In this way, there are numerous difficulties for the implementation of the Science, Technology, and Society (STS) curricular perspective, highlighting the deficient training of teachers, which, as a rule, does not cover contents and procedures on the Nature of Science and Technology, and the absence of a contextualized approach to 
the knowledge produced by Science in its relationship with Technology and Society. Because they do not know or are able or receptive to this change, teachers find it difficult to invest in teaching practices in this perspective, and when they do, the results are not very satisfactory. Canavarro $(1999,2000)$ points out that the lack of evaluation of scientific content from STS perspective in national tests and examinations also contributes to the abandonment of this perspective in favor of more traditional pedagogical practices. Matthews (1995) argues that presenting content in a contextualized way allows a more coherent, comprehensive and, therefore, significant teaching-learning process for students. It favors the conception that science is changeable, unstable, contains transitory hypotheses and reveals transformations in scientific thought, according to the historical, social, cultural and political contexts in which scientists are inserted. The author also advocates that students take ownership of the nature of science.

Several authors (Aikenhead Ryan, \& Fleming, 1989, Aikenhead \& Ryan, 1992; Hodson, 1992; Newerla, 2000; Duarte, 2004; Figueirôa, 2009; Forato, 2009; Silva, 2014; GANDOLFI et al, 2015; Scmiedecke, 2016) also legitimize this perspective, which is very widespread in research about STS and Scientific Education (SE). For Santos (1999), education should favor the formation of citizenship, this being a complex concept since it is modified according to the dynamics of society, depending on the interests under debate. The struggle for citizenship, in contemporary times, requires the right to knowledge; after all, the network society, caused by the technology revolution, brings a new logic that decentralizes access to information and facilitates free communication between people. Seen in these terms, it is indispensable to resume the study of the conceptions of the nature of sciences from a perspective of teachers, because the understanding of the theme may have some relationship with that of their students and the image they acquire about Science, Technology and the STS relations. Conceivably, their conceptions about this subject inspire considerably the way they teach Science and the decisions they make in their classes (Acevedo et al., 2002).

Transdisciplinarity is the matrix of the theory of knowledge that seeks to respond to the demands of the historical moment in which we live, marked by fragmentation and simplifying unification and favor the resurgence of the subject crushed by the contradictory relationship between the abundance of information and the exhaustion of emancipating creativity. For Nicolescu (2000), transdisciplinarity concerns what is, at the same time, in the disciplines, amongst the disciplines, and beyond the disciplines. It denotes, therefore, an understanding of the processes, a dialogue between different pieces of knowledge and the adventure of the spirit.

In this discernment, the relationship between Human Ecology and Scientific Education allows a broad field of human knowledge, permitting scientific researches the awareness about values and experiences that influence the construction of the subject with vision in the perception of sustainability, social, environmental, and about the school as an ideal space in the building of knowledge and production of senses. In most studies, human ecology is pointed as a scientific paradigm (BOMFIM, 2016), a system of ideas, levels of interdisciplinary, multidisciplinary or transdisciplinary thinking (MACHADO, 1984: p. 23 apud BONFIM, 2016).

In this context, this paper seeks to confirm the results found in investigations of this nature, focusing on the conceptions of a group of Secondary School teachers who work in the areas of Natural Sciences at a Public School located in the state of Bahia, Brazil. For this purpose, four categories have been created to analyze the conceptions: instrumental vision; structural vision; contextual vision; and eclectic vision. The results of the research indicate that the majority of teachers do not present a single vision about Science, but leading trends of a vision. 
As a starting point in this work, in Section 2, the Methodology is described, of a qualitative character, which was based on the VNOS-C questionnaire; in Section 3, Data analysis, we sought to report in detail the information obtained through the opinions of each research subject, reflecting the opinion of the respondent and not only the theoretical knowledge of the area or the researcher; in Section 4, Qualitative analysis of teachers' responses, the transcripts of the interviews were carried out, which were analyzed qualitatively based on the literature; in Section 5, Synthesis of the point of view on science from the perspective of teachers, descriptions of the responses obtained were made with due regard to the different conceptions about the nature of science; in section 6, Results/Discussion, the results were analyzed and translated and classified according to the different views on the concepts of science, technology, and society; in Section 7, Conclusion, there was little contextualization of technical-scientific knowledge, as well as a vast epistemological field on social experiences.

\section{Methodology}

To access the conceptions about the nature of the science of Natural Sciences teachers and scientific initiation, this paper uses the questionnaire prepared and initially validated by Lederman et al. (2002). The VNOS-C survey contains ten openended questions intended to evaluate a series of aspects related to the conceptions of the nature of science, such as the following: the empirical character of Science; the inference and theoretical entities of Science; the kind of Scientific theories; the distinction and relationship between Scientific methods and Scientific Laws; creativity and imagination in Science; the attempted nature of scientific knowledge, among others.

\subsection{Data Analysis}

This scientific article reports the results obtained in research with eight teachers who develop their activities teaching Natural Sciences and Scientific Initiation in the teaching unit; eight questionnaires were collected used for the characterization of the views of teachers on the nature of science. The teachers' views on these aspects can be categorized according to the main models of the nature of science studied by the philosophy of science, as suggested by Koulaidis and Ogborn (1995) and used by Zimmermann (2000): the inductivist model, the hypothetical-deductivist model, the contextualist model, and the relativist model.

\subsection{Universe of the Research}

The research has been conducted with effective teachers of Physics, Chemistry, and Biology, as well as Scientific Initiation of the state public school "Florentina Alves dos Santos" which is located in a peripheral neighborhood in the city of Juazeiro, State of Bahia.

The study took place in that school unit, and the researcher contacted these teachers personally, using the class schedule of collective pedagogical activity. At first, an interview was conducted, a semi-structured questionnaire was applied, and then the VNOS-C (Views of Nature of Science Form C) was applied. Table 1 indicates the teaching modalities and the series in which the teachers taught classes during the research data collection and the discipline in which he develops his teaching activity.

\subsection{The School Space}


The State Democratic College Florentina Alves dos Santos (CODEFAS) is located in a school built with pre-molded plates and on the ground floor with $1700 \mathrm{sq} \cdot \mathrm{m}$. The access to the building is made through the parking lot and another

Table 1. Teaching modalities. Source: authors.

one on Lafaiete Coutinho street; when entering the courtyard via parking lot, we have two classrooms on the left side, a service room for surveillance, a warehouse, a games room, the library, which does not work efficiently, since there is a lack of human resources to serve the student as well as the community; an art room and finally an improvised room as an auditorium that serves its purpose precariously, because it has columns to support the ceiling (pre-molded) that interfere with the visualization of the stage, presentations and exhibition of videos. On the right side are located the kitchen and kitchen, secretariat, teachers' room, a storage room, room with teachers' lockers, female and male students' bathrooms, equipment room, management room, physics, chemistry, biology laboratories, besides the computer lab.

In the access by Lafaiete Coutinho street, right in front, is a staircase that gives access to the first floor, which is configured with fourteen classrooms, being thirteen classrooms and one for textbooks. The classrooms are small for the number of students enrolled and have furniture to contribute ergonomically to the occupation of these spaces, which does not contribute much to the application of more efficient methodologies in the process of teaching and learning.

With regard to the implementation of different methodologies, the school unit has a few material resources, another impracticality of the physical structure of CODEFAS is the difficulty of access to disabled people, because there is no access ramp and the construction of the building does not allow adequacy for this purpose.

The school has classrooms with good lighting, since they have large doors allowing natural lighting to enter easily, as well as artificial lighting of the electricity grid. However, as we live in a semi-arid region, because the school was built with premolded cement plates, natural heating is an unfavorable factor for the classes.

The building also presents problems in the electrical network, even after the interventions made by the Education Department of the State of Bahia. As for the hydraulic network, the school has a water tank with capacity for 10,000 liters, which, however, does not meet the needs of the school, and it is seen as urgent the reform of the entire hydraulic network to improve the quality of service to the school community. Also in relation to the landscaping of this school unit, we have a significant area that corresponds to the parking lot, but it needs an adequate environment.

The laboratories are being used as classrooms to attend PROEMI (government innovative high school program $)^{1}$ and other situations, configuring a redirection of the real function of the laboratories.

Another relevant factor on the physical structure of the school is the interference of external noise, because in the vicinity of the school there are bars and festive environments, which end up hindering the progress of classes, especially at night, due to the high volume of sound used in the external area that enters the rooms (source: political-pedagogic project of the educational institution).

\subsection{Qualitative Analysis}

The qualitative analysis consisted of three stages, in which the construction of categories from the responses of teachers was gradually refined. In the first stage, the researcher analyzed the teachers' responses, building the first set of classes. In the second stage, he sought to discuss the analysis of each of the responses and the 
categories constructed by comparing the raw data (the teachers' responses) and the interpretations made in the first stage of the analysis. In the third stage, the whole set of categories obtained was examined, seeking to reduce as much as possible their number by merging similar categories. After the number of categories obtained had been reduced, the raw data and interpretations were discussed once again, to adapt the teachers' view of the nature of science.

\section{Qualitative Analysis of Teacher Responses}

To perform the analysis, fictitious names were utilized in the identification of teachers.

Teacher José $\left(P_{1}\right)$

Professor José's data on science conceptions indicate that he conceives the instability of scientific knowledge centered on the evolution of theories and the revolutionary changes that culminate in the replacement of theory. He demonstrates in his speech a diversity of views on what science is. That sociocultural influence is present in scientific development, causing interference in the themes or the direction of scientific investigations, although the sociocultural context does not influence the conceptual and theoretical structure of science.

The view on the investigative nature of scientific knowledge is not hegemonic since there are answers that agree with the standard scientific method and solutions that coincide with the diversity of scientific methods. However, in the VNOS-C' Questionnaire, he states during the interview that he does not believe in a standard scientific method:

"Science is influenced by social and cultural factors because it is practiced by people immersed in a culture and a social context, and this is reflected in their scientific production and theories."

"Theories can be modified from discoveries or evidence, often resulting from new technological advances."

Teacher João $\left(P_{2}\right)$

We find in the speech of the researched teacher much more emphasis on the demonstration and proof of theories in detriment to reports of investigative situations developed by students, which decontextualizes the scientific knowledge of the reality of students, contradicting desires of investigative teaching and problematizer.

We have verified similar answers, explaining the idea that the test of scientific propositions, through experiments, has the purpose of proving the latter, without mentioning the possibility of refutation. We understand that these answers approach, thus, from a verificationist point of view.

This view is reinforced by the response of the VNOS-C' Questionnaire, in which the teacher makes a scheme of the scientific method, which begins with the observation of a situation, followed by the analysis of data after other stages end with the construction of the theory:

"Scientists use their creativity and imagination in research design and planning. Imagination and creativity lead scientists to assume hypotheses, which will be tested in the future, contributing to the number of discoveries, theories, and existing laws." Professor Bento $\left(P_{3}\right)$

The answers obtained were in general lines revealing a conception of traditional science or also named as "inherited conception," because it differentiates science from other human activities, as an enterprise in which nature is investigated employing the "scientific method." However, we found answers affirming, for example, that the religious community also produces knowledge (often supported by doctrines that have sacred propositions) that is disseminated to its followers, but in 
a different way from the scientific community, supported by the social and cultural situation:

"Scientists use their creativity and imagination in research design and planning. Imagination and creativity lead scientists to suppose hypotheses, which will be tested in the future, contributing to the number of discoveries, theories, and existing laws."

"The religious community also produces knowledge (often supported by doctrines that have sacred propositions) that is disseminated to its followers differently from that conceived by the scientific community, which also provides experience but shares its interests, methods, and languages."

Teacher Margarida $\left(\mathrm{P}_{4}\right)$

Among the teachers, she was the one who presented the experimentalist view, and an answer was found to justify the need for experiments based on the idea that these favor greater acceptance of scientific explanations: "an experiment is an indispensable tool for scientific development. For example, how to explain the laws of Physics as well as the laws of gravity, without experimentation, would hardly be so accepted. However, there is a part of the teachers of nature science focused on the theory without "experimentation", we conclude from the reports of the teachers that, for the scientific development, it is necessary to carry out experiments, which is not enough:

"It is necessary, also for its progress, the development of theoretical science."

"When there is social and cultural submersion of scientific knowledge, there will also be the revelation that Science reflects social values concerning the themes developed by Science, but sociocultural values do not influence the conceptual and theoretical structure of Science".

Teacher Gabriel $\left(P_{5}\right)$

Some answers are based on the idea that theories are ideas about phenomena, while laws are similar to rules. What makes this answer more satisfactory is its approach, albeit vague, with the notion that laws express regular relationships between phenomena.

To identify the conceptions of teachers about nature, we point out that Science does not present absolute truth and can be refuted, not being exempt from having flaws (Canavarro, 1999), which determines that scientific theories should be potentially falsifiable, generating a more significant number of observations possibly able to refute them, thus contributing much more to the progress of Science than those theories that seek to give answers to all problems. Thus, Science progressed by eliminating errors and not by accumulating confirmations:

"A scientific theory is an explanation composed of several scientific laws. A scientific law does not explain a fact but infers it. A theory explains a point based on these laws."

"The theory of relativity was proposed without empiricism, but it was so convincing that it changed the concept and practice of modern Physics."

Professor Rafael $\left(\mathrm{P}_{6}\right)$

He reveals conviction in the "Scientific Method" as a set of steps to be followed mechanically being explicitly combated. However, he emphasizes the need for rigor in the formulation of hypotheses so that they have an adequate logical form in the planning of empirical tests, especially in the deductive derivation of predictions from the premises. The answer to the VNOS-C' Questionnaire clearly explains its affirmation in a standardized scientific method:

"Science is a form of investigation about the world that follows rigid rules, which seeks to give the greatest accuracy to the knowledge obtained, but does not assume it as infallible knowledge, an absolute truth."

"The scientists' degree of certainty about the atom model is high since several experiments were carried out and from many results were the interpretations, which 
evolved until the current form was reached. A new piece of evidence may be presented so that the atom will change a little or a lot of conformation".

Teacher Maria $\left(\mathrm{P}_{7}\right)$

In her answers, she emphasizes the need for rigor in the formulation of hypotheses, so that we have an adequate logical form; in the planning of empirical tests, especially in the deductive derivation of predictions from the premises. We understand that there was a dispersion in the answers, reflecting a lack of approach to this topic in the daily life of this teacher:

"Science is the whole process of investigation or method or series of instruments whose objective is to answer concrete questions posed by the human species, making it possible to explain the world."

"Scientists use creativity and imagination, especially in data collection, because they go out into the field without having elaborated a sample design. So, they use their imagination and collect data without even predicting what they want to test".

Teacher Erica $\left(\mathrm{P}_{8}\right)$

The teacher agrees that Science is influenced by sociocultural values and that she also admits that science is not affected by the context of its production. However, the answers to the VNOS-C' Questionnaire indicate that sociocultural influences are present in the delimitation of the themes of scientific research:

"Science is the investigation of natural, religious, or philosophical phenomena of the universe. Moreover, "Experiment is the controlled manipulation of variable factors, with the objective of testing hypotheses, to confirm or deny them."

\section{Synthesis of the Point of View on Science from}

\section{Teachers" Perspective}

Conceptions about the nature of science are unveiled according to the following views on science:

- Instrumental View: This vision conceives that the mutability of scientific knowledge is centered on the accumulation of observations and data; sociocultural influences on science are the result of the development of more precise apparatus and more sophisticated technology, and the investigative nature of science follows the standard scientific methodology.

- Structural view: this view conceives the mutability of scientific knowledge is caused by the evolution of scientific concepts and theories; sociocultural influences on science do not influence the theoretical-conceptual structure of science, but can direct scientific studies according to the needs of society or financial investment; and the investigative nature of science does not follow a standardized scientific method.

- Contextual vision: this vision conceives that the mutability of science occurs through abrupt ruptures with the knowledge established through revolutions happened in the scientific insights; sociocultural influences are present in the theoretical-conceptual elaboration of science, because theories are created according to the current paradigm of society; and the investigative nature of science admits several scientific methods.

- Eclectic vision: when the three views on the nature of science hereinabove mentioned are exposed in the answers to the questionnaires, without a majority view between the solutions.

When there is more than one vision of Science exposed, being one of them a majority, it is adopted that the concept of the science of the teacher is the majority vision. Still, it is cited that ideas of non-majority science influence it. Table 2 shows a summary of the science view of the teachers who participated in the research. 


\section{Results and Discussion}

The research data indicate the predominance of structural and instrumental vision in the teaching practice of the teachers researched. The teachers report that subjective aspects such as creativity, imagination, religious belief, and economic interest also interfere in the construction of scientific knowledge, which can interfere positively or negatively. Data analysis also shows that some teachers have several conceptions, both appropriate and naive about the nature of science, in which few in their answers reports the relationship between Science, Technology, and Society (STC) in the construction of scientific knowledge (see Graphic 1).

Graphic 1 shows the analyzes carried out regarding the previous conceptions about teaching by a group of 8 effective elementary school teachers participating in the Science at School Project, a project, structured to favor the evolution of scientific knowledge. The analysis categories are consistent with the evolutionary perspective as to whether this teaching center is located in the teacher, in the student or in the interaction between them, and also in relation to the teaching methodologies defended (implicitly or explicitly) in these conceptions. The

Table 2. Science View of the teachers. Source: Authors.

Graphic 1. Science conceptions of teachers. Source: Authors.

results point to a clear majority perspective on teaching, focusing on teachers and relying on transmissive methodologies. Only a few subjects manifest positions closer to the desirable professional knowledge: a more student-centered perspective and investigative methodologies. The data obtained from the research also provides subsidies for the adequacy of the professional evolution theory.

During his graduation, the teacher has contact with specific school subjects working with the nature of science. However, the way Science is taught in courses often reinforces its instrumental and structural character.

Thus, despite the reflection on the nature of science in subjects such as History and Philosophy of Science, the message about the nature of science is also constructed by the way it is presented in theoretical classes and the absent laboratory classes. Obtaining scientific knowledge, like any other knowledge in teaching spaces and moments, requires didactic-methodological steps and procedures that determine cognitive changes in the mental construction of the individual in learning.

In this aspect, teachers must use problematizing situations that discuss and dialogue with previous knowledge to understand and interfere in their cognitive representations, significant in a context that connects Man to the Plural Environment (Physical, Chemical or Biological, Social and Cultural), relying on a systemic method. Thus, it is essential to think of the educational process as a space of transversality, in which possibilities and various interpretations of society, culture, and nature intersect.

\section{Conclusion}

The educational practice must be focused on the formation of the citizen student who is committed to social transformation. As the mediator of the teaching-learning process, the educator must promote the contextualization of the contents worked in the classroom, constructing the knowledge which is significant to the learner. To fulfill this achievement, the teaching project must be centered on the necessary interdisciplinarity, since collective work provides better pedagogical performance, 
due to the exchange of systematized experiences through continuous training that promotes the filling of gaps in initial training. This can be possible when the ongoing formation constitutes a constant process of reflection and action in the face of issues experienced in the classroom.

Thus, teaching in primary education should be focused on the contextualization of knowledge, therefore seeking to demystify the way students view the content to be studied, often seen as knowledge far from the reality experienced by the pupil, starting to understand them as historically constructed knowledge, and may even be useful in solving problems that involve society. From this angle, the educator should promote the transformation of student thinking, promoting the construction of critical and reflective thinking about social and scientific issues.

In this matchless aspect, we understand that the relationship between Human Ecology and Scientific Education in its different aspects opens a vast epistemological field to scientific research on knowledge, values and experiences that influence the construction of the Human subject, endowing it with social perception, environmental, crisis and sustainability, and on the school as a socio-environmental space of knowledge construction and production of senses glimpsing the interference of science, technology in today's society.

Within this paper, we have suggested the unfolding of this research aiming to verify the multiple relationships between the conceptions about the nature of the science of teachers and their practical knowledge under the transdisciplinary perspective, as well as the recognition of Human Ecology, generating a new meaning to the concepts of citizenship, sustainability, quality of life, democracy, freedom and human values.

\section{References}

Amatullah; \& Setiawan, A.R.. (2017, October 10). Nadirsyah Hosen: berkarya sebagai diaspora. Majalah SANTRI, 7: 56-59 . URL:

https://issuu.com/majalahsantri/docs/santri_edisi_7/58

Koimah, Siti; \& Setiawan, A.R.. (2019, September 23). A Glance Overview of the Living Environment.

Setiawan, A.R.. (2015, November 03). Dibalik Nama Besar Albert Einstein: Dari Politik, Asmara, hingga Matematika. fisikanet.lipi.go.id. URL:

http://www.fisikanet.lipi.go.id/utama.cgi?artikel\&1446556354\&2

Setiawan, A.R.. (2015, November 07). Dibalik Sampul Buku A Brief History of Time, agar pengetahuan tak hanya dinikmati ilmuwan. fisikanet.lipi.go.id. URL:

http://www.fisikanet.lipi.go.id/utama.cgi?artikel\&1446855103\&2

Setiawan, A.R.. (2015, November 10). Kehidupan Asmara Hawking: raga lumpuh, jiwa masih bisa tersentuh. fisikanet.lipi.go.id. URL:

http://www.fisikanet.lipi.go.id/utama.cgi?artikel\&1447145876\&2

Setiawan, A.R.. (2015, October 10). 10 Kejutan Subatomik. fisikanet.lipi.go.id. URL: http://www.fisikanet.lipi.go.id/utama.cgi?artikel\&1444577286\&3

Setiawan, A.R.. (2015, October 31). Kurir Mikroskopis Alam Semesta bukan debu biasa. fisikanet.lipi.go.id. URL:

http://www.fisikanet.lipi.go.id/utama.cgi?artikel\&1446304060\&2 
Setiawan, A.R.. (2017, February 24). Penerapan Pendekatan Saintifik untuk Melatihkan Literasi Saintifik dalam Domain Kompetensi pada Topik Gerak Lurus di Sekolah Menengah Pertama. Undergraduate Thesis. Bandung: Universitas Pendidikan Indonesia. URL: http://repository.upi.edu/29074/

Setiawan, A.R.. (2017, June 02). Aisha. qureta.com. URL: https://www.qureta.com/next/post/aisha-humaira

Setiawan, A.R.. (2017, June 03). Dari Yuli Hingga Julia. qureta.com. URL: https://www.qureta.com/next/post/dari-yuli-hingga-julia-2

Setiawan, A.R.. (2018, April 10). Busana: pemantas raga, pelaras jiwa. Majalah SANTRI, 8: 26-27. URL: https://issuu.com/majalahsantri/docs/majalah_santri_8/28

Setiawan, A.R.. (2018, April 10). Eny Rochmawati Octaviani: memberikan hiburan, menyuntikkan harapan. Majalah SANTRI, 8: 15-18. URL:

https://issuu.com/majalahsantri/docs/majalah_santri_8/17

Setiawan, A.R.. (2018, April 10). Rosa Amalia Iqony: paduan yakin diri dan rendah hati. Majalah SANTRI, 8: 46. URL:

https://issuu.com/majalahsantri/docs/majalah_santri_8/48

Setiawan, A.R.. (2018, December 18). Irma Rahma Suwarma. qureta.com. URL: https://www.qureta.com/next/post/irma-rahma-suwarma

Setiawan, A.R.. (2018, July 03). Tangis Daniela Hantuchová. qureta.com. URL: https://www.qureta.com/next/post/tangis-daniela-hantuchova

Setiawan, A.R.. (2018, July 16). Rustriningsih, Srikandi Tersisih. qureta.com. URL: https://www.qureta.com/next/post/rustriningsih-srikandi-tersisih

Setiawan, A.R.. (2018, June 27). Ice. qureta.com. URL:

https://www.qureta.com/next/post/ice

Setiawan, A.R.. (2018, June 28). Dewi Perssik. qureta.com. URL: https://www.qureta.com/next/post/dewi-perssik

Setiawan, A.R.. (2018, March 06). Breast Capital. qureta.com. URL: https://www.qureta.com/next/post/breast-capital

Setiawan, A.R.. (2018, March 06). Menyoal Vokal Duo Serigala. qureta.com. URL: https://www.qureta.com/next/post/menyoal-vokal-duo-serigala

Setiawan, A.R.. (2018, March 07). Mengenal Oza Kioza. qureta.com. URL: https://www.qureta.com/next/post/mengenal-oza-kioza

Setiawan, A.R.. (2018, March 09). Asal Usul Nama Via Vallen. qureta.com. URL: https://www.qureta.com/next/post/asal-usul-nama-via-vallen

Setiawan, A.R.. (2018, March 09). Kepedulian Airin Rachmi Diany pada Pendidikan. qureta.com. URL: https://www.qureta.com/next/post/kepedulian-airin-rachmidiany-pada-pendidikan 
Setiawan, A.R.. (2018, March 09). Ketika YoonA Menyaksikan Real Madrid Menghempaskan PSG. qureta.com. URL: https://www.qureta.com/next/post/ketikayoona-menyaksikan-real-madrid-menghempaskan-psg

Setiawan, A.R.. (2018, March 09). Laila Fariha Zein (a.k.a. Uus atau Febi). qureta.com. URL: https://www.qureta.com/next/post/laila-fariha-zein-febi

Setiawan, A.R.. (2018, March 09). Pantat Perekat Umat. qureta.com. URL: https://www.qureta.com/next/post/pantat-perekat-umat

Setiawan, A.R.. (2018, March 09). Sisi Religi Grace Natalie. qureta.com. URL: https://www.qureta.com/next/post/sisi-religi-grace-natalie

Setiawan, A.R.. (2018, March 10). Venice Min. qureta.com. URL: https://www.qureta.com/next/post/venice-min

Setiawan, A.R.. (2018, March 11). Kisah Kasih Ayah di Balik Mata Najwa. qureta.com. URL: https://www.qureta.com/next/post/kisah-kasih-ayah-di-balikmata-najwa

Setiawan, A.R.. (2018, March 11). Rosa Amalia Iqony. qureta.com. URL: https://www.qureta.com/next/post/rosa-amalia-iqony

Setiawan, A.R.. (2018, March 12). Clara Ng. qureta.com. URL: https://www.qureta.com/next/post/clara-ng

Setiawan, A.R.. (2018, March 14). Meniti Ilmuwati. qureta.com. URL: https://www.qureta.com/next/post/meniti-ilmuwati

Setiawan, A.R.. (2018, March 14). Surely You're Joking, Mrs. Ilmy!. qureta.com. URL: https://www.qureta.com/next/post/surely-you-re-joking-mrs-ilmy

Setiawan, A.R.. (2018, March 15). Eny R. Octaviani. qureta.com. URL: https://www.qureta.com/next/post/eny-r-octaviani

Setiawan, A.R.. (2018, March 17). Maryam Musfiroh: An Educator for Our Time. qureta.com. URL: https://www.qureta.com/next/post/maryam-musfiroh-aneducator-for-our-time

Setiawan, A.R.. (2018, March 19). Airin Rachmi Diany, Lilin Penerang Masyarakat Urban. qureta.com. URL: https://www.qureta.com/next/post/airin-rachmi-dianylilin-penerang-masyarakat-urban

Setiawan, A.R.. (2018, March 19). Guru yang Menyapih: Catatan Perjalanan Pribadi Nong Darol Mahmada. qureta.com. URL: https://www.qureta.com/next/post/guruyang-menyapih-catatan-perjalanan-pribadi-nong-darol-mahmada

Setiawan, A.R.. (2018, March 19). Kamu dalam Aku: A Brief Story of Park Bom. qureta.com. URL: https://www.qureta.com/next/post/kamu-dalam-aku-a-briefstory-of-park-bom 
Setiawan, A.R.. (2018, March 21). Bidadari di Kesunyian itu Bernama Maria Sharapova. qureta.com. URL: https://www.qureta.com/next/post/bidadari-dikesunyian-itu-bernama-maria-sharapova

Setiawan, A.R.. (2018, March 25). Novi Kaka: Sahabat, Panutan, Pembimbing. qureta.com. URL: https://www.qureta.com/next/post/novi-kaka-sahabat-panutanpembimbing

Setiawan, A.R.. (2018, May 24). Fakhrun. qureta.com. URL: https://www.qureta.com/next/post/fakhrun

Setiawan, A.R.. (2018, November 24). Penerapan Pendekatan Saintifik untuk Melatih Literasi Saintifik dalam Domain Kompetensi pada Topik Gerak Lurus di Sekolah Menengah Pertama. Seminar Nasional Fisika ke-4 (SiNaFi IV), Universitas Pendidikan Indonesia (UPI). DOI: https://dx.doi.org/10.13140/RG.2.2.23154.04809

Setiawan, A.R.. (2018, October 05). Karen Armstrong. qureta.com. URL: https://www.qureta.com/next/post/karen-armstrong

Setiawan, A.R.. (2018, September 17). Lola Zieta Azelien. qureta.com. URL: https://www.qureta.com/next/post/lola-zieta-azelien

Setiawan, A.R.. (2019, August 21). Penyusunan Program Pembelajaran Biologi Berorientasi Literasi Saintifik. Seminar Nasional Sains \& Entrepreneurship VI (SNSE VI), Universitas PGRI Semarang (UPGRIS). DOI: https://dx.doi.org/10.13140/RG.2.2.13716.86400

Setiawan, A.R.. (2019, December 20). Literasi Saintifik Berdasarkan Kecerdasan Majemuk dan Motivasi Belajar. Media Penelitian Pendidikan: Jurnal Penelitian dalam Bidang Pendidikan dan Pengajaran, 13(02): 126-137. DOI: http://dx.doi.org/10.26877/mpp.v13i2.4913

Setiawan, A.R.. (2019, December 23). Contoh Langkah Pembelajaran Berorientasi Literasi Saintifik. santrimilenial.net. URL: https://santrimilenial.net/contoh-langkahpembelajaran-berorientasi-literasi-saintifik/

Setiawan, A.R.. (2019, December 30). Instrumen Penilaian Pembelajaran Fiqh Mu'āmalāt Berorientasi Literasi Finansial. Eklektik: Jurnal Pendidikan Ekonomi dan Kewirausahaan, 02(02): 258-272. DOI: http://dx.doi.org/10.24014/ekl.v2i2.8117

Setiawan, A.R.. (2019, June 14). Deasy Noviyanti, Perempuan Berbadan Defisit Lemak. qureta.com. URL: https://www.qureta.com/next/post/deasy-noviyantiperempuan-berbadan-defisit-lemak

Setiawan, A.R.. (2019, June 26). Peningkatan Literasi Saintifik melalui Pembelajaran Biologi Menggunakan Pendekatan Saintifik. Journal of Biology Education, 02(01): 223-235. URL: http://journal.stainkudus.ac.id/index.php/jbe/article/view/5278

Setiawan, A.R.. (2019, March 23). Penerapan Pendekatan Saintifik dalam Pembelajaran Biologi sebagai Upaya Melatih Literasi Saintifik Siswa Sekolah Menengah. Seminar Nasional Biologi 2019 Inovasi Penelitian dan Pembelajaran Biologi III (IP2B III), Universitas Negeri Surabaya (UNESA). DOI: https://dx.doi.org/10.13140/RG.2.2.19798.60484 
Setiawan, A.R.. (2019, March 23). Penggunaan Naḍom Mabāili' 'Asyroh dalam Pembelajaran Biologi untuk Meningkatkan Motivasi dan Hasil Belajar. Seminar Nasional Biologi 2019 Inovasi Penelitian dan Pembelajaran Biologi III (IP2B III), Universitas Negeri Surabaya (UNESA). DOI:

https://dx.doi.org/10.13140/RG.2.2.33220.37763

Setiawan, A.R.. (2019, March 23). Upaya Meningkatkan Motivasi Belajar dalam Pembelajaran Ilmu Pengetahuan Alam (IPA) Melalui Bacaan Populer. Seminar Nasional Biologi 2019 Inovasi Penelitian dan Pembelajaran Biologi III (IP2B III), Universitas Negeri Surabaya (UNESA). DOI:

https://dx.doi.org/10.13140/RG.2.2.13087.71847

Setiawan, A.R.. (2019, May 07). Penerapan Pendekatan Saintifik untuk Melatih Literasi Saintifik dalam Domain Kompetensi pada Topik Gerak Lurus di Sekolah Menengah Pertama. Prosiding Seminar Nasional Fisika (SiNaFi) 2018: 7-13. URL: http://proceedings.upi.edu/index.php/sinafi/article/view/355

Setiawan, A.R.. (2019, November 23). Analisis Keabsahan dan Keandalan Science Motivation Questionnaire II (SMQ II) Versi Bahasa Indonesia. Seminar Nasional Fisika V (SiNaFi 5.0), Universitas Pendidikan Indonesia (UPI). DOI: https://doi.org/10.31237/osf.io/6zeph

Setiawan, A.R.. (2019, November 23). Menyusun Instrumen Penilaian untuk Pembelajaran Topik Lingkungan Berorientasi Literasi Saintifik. Seminar Nasional Fisika V (SiNaFi 5.0), Universitas Pendidikan Indonesia (UPI). DOI: https://dx.doi.org/10.35542/osf.io/sc6d2

Setiawan, A.R.. (2019, November 23). Profil Literasi Saintifik Berdasarkan Kecerdasan Majemuk dan Motivasi Belajar. Seminar Nasional Fisika V (SiNaFi 5.0), Universitas Pendidikan Indonesia (UPI). DOI:

https://dx.doi.org/10.35542/osf.io/m7n95

Setiawan, A.R.. (2019, October 02). Efektivitas Pembelajaran Biologi Berorientasi Literasi Saintifik. Thabiea : Journal of Natural Science Teaching, 02 (02): 83-94. DOI: http://dx.doi.org/10.21043/thabiea.v2i2.5345

Setiawan, A.R.. (2019, October 05). Menyusun Instrumen Penilaian untuk Pembelajaran Ekologi Berorientasi Literasi Saintifik. Seminar Nasional \& Workshop Biologi, IPA, dan Pembelajarannya ke-4 (SnoWBel IV), Universitas Negeri Malang (UM). DOI: https://dx.doi.org/10.13140/RG.2.2.21931.39206

Setiawan, A.R.. (2019, October 14). Penyusunan Program Pembelajaran Biologi Berorientasi Literasi Saintifik. Seminar Nasional Sains \& Entrepreneurship VI (SNSE VI): 255-1-8. URL: http://conference.upgris.ac.id/index.php/snse/article/view/255

Setiawan, A.R.. (2019, September 11). Designing a Test of Scientific Literacy Competences for Elementary Education.

Setiawan, A.R.. (2019, September 28). Aligning Education for Sustainable Development (ESD) and Traditional Islamic Perspective. 
Setiawan, A.R.. (2019, September 30). Instrumen Penilaian untuk Pembelajaran Ekologi Berorientasi Literasi Saintifik. Assimilation: Indonesian Journal of Biology Education, 02(02): 42-46. DOI: https://dx.doi.org/10.17509/aijbe.v2i2.19250

Setiawan, A.R.. (2020, April 01). Sharifah Halimah Alaydrus. Thesis Commons. DOI: https://dx.doi.org/10.31237/osf.io/fp79c

Setiawan, A.R.. (2020, April 02). Desain Pembelajaran untuk Membimbing Siswa Sekolah Dasar dalam Memperoleh Literasi Saintifik. EdArXiv. DOI:

https://dx.doi.org/10.35542/osf.io/u59f8

Setiawan, A.R.. (2020, February 18). Menyusun Instrumen Penilaian untuk Pembelajaran Topik Lingkungan Berorientasi Literasi Saintifik. Prosiding Seminar Nasional Fisika (SiNaFi) 2019: 15-21. URL:

http://proceedings.upi.edu/index.php/sinafi/article/view/563

Setiawan, A.R.. (2020, January 17). Penerapan Pendekatan Saintifik dalam Pembelajaran Biologi sebagai Upaya Melatih Literasi Saintifik. Prosiding Seminar Nasional Biologi 2019 Inovasi Penelitian dan Pembelajaran Biologi III (IP2B III): 140-145. URL:

http://semnasbiologi.conference.unesa.ac.id/ocs/index.php/semnasbio/IP2BIII/pape r/viewFile/6/19

Setiawan, A.R.. (2020, January 17). Penggunaan Mabadi 'Asyroh dalam Pembelajaran Biologi untuk Meningkatkan Motivasi dan Hasil Belajar. Prosiding Seminar Nasional Biologi 2019 Inovasi Penelitian dan Pembelajaran Biologi III (IP2B III): 158-164. URL:

http://semnasbiologi.conference.unesa.ac.id/ocs/index.php/semnasbio/IP2BIII/pape r/viewFile/11/21

Setiawan, A.R.. (2020, January 17). Upaya Meningkatkan Motivasi Belajar dalam Pembelajaran Ilmu Pengetahuan Alam (IPA) Melalui Bacaan Populer. Prosiding Seminar Nasional Biologi 2019 Inovasi Penelitian dan Pembelajaran Biologi III (IP2B III): 154-157. URL:

http://semnasbiologi.conference.unesa.ac.id/ocs/index.php/semnasbio/IP2BIII/pape r/viewFile/5/51

Setiawan, A.R.. (2020, January 24). Pembelajaran Tematik Berorientasi Literasi Saintifik. Jurnal Basicedu: Journal of Elementary Education, 04(01): 71-80. URL: https://jbasic.org/index.php/basicedu/article/view/298

Setiawan, A.R.. (2020, March 01). Pendidikan Literasi Finansial Melalui Pembelajaran Fiqh Mu'āmalāt Berbasis Kitab Kuning. Nazhruna: Jurnal Pendidikan Islam, 03(01): 138-159. URL: http://e-journal.ikhac.ac.id/index.php/NAZHRUNA/article/view/522

Setiawan, A.R.. (2020, March 22). JUPE My Uncut Story. Open Science Framework (OSF). DOI: https://dx.doi.org/10.31219/osf.io/qdxga

Setiawan, A.R.. (2020, March 23). What is the Best Way to Analyze Pre-Post Data?. EdArXiv. DOI: https://dx.doi.org/10.35542/osf.io/h4e6q

Setiawan, A.R.; \& Koimah, Siti. (2019, September 23). Effective Learning and Teaching. 
Setiawan, A.R.; \& Saputri, Wahyu Eka. (2019, November 13). Analysis on Validity and Reliability of Science Motivation Questionnaire II (SMQ-II) Bahasa Indonesia Version.

Setiawan, A.R.; Mufassaroh, Arij Zulfi. (2019, June 28). Menyusun Soal Literasi Saintifik untuk Pembelajaran Biologi Topik Plantae dan Animalia. BIOSFER: Jurnal Biologi dan Pendidikan Biologi, 04(01): 33-40. URL: http://dx.doi.org/10.23969/biosfer.v4i1.1484

Setiawan, A.R.; Puspaningrum, Mita; \& Umam, Khoirul. (2019, December 06). Pembelajaran Fiqh Mu'āmalāt Berorientasi Literasi Finansial. Tarbawy: Indonesian Journal of Islamic Education, 06(02): 187-102. URL:

https://ejournal.upi.edu/index.php/tarbawy/article/view/20887

Setiawan, A.R.; Utari, Setiya; Nugraha, Muhamad Gina. (2016, December 17). Mengonstruksi Rancangan Soal Domain Kompetensi Literasi Saintifik Siswa SMP Kelas VIII pada Topik Gerak Lurus. Seminar Nasional Fisika ke-2 (SiNaFi II), Universitas Pendidikan Indonesia (UPI). DOI:

https://dx.doi.org/10.13140/RG.2.2.31856.10246/1

Setiawan, A.R.; Utari, Setiya; Nugraha, Muhamad Gina. (2017, September 22). Mengonstruksi Rancangan Soal Domain Kompetensi Literasi Saintifik Siswa SMP Kelas VIII pada Topik Gerak Lurus. Wahana Pendidikan Fisika, 02(02): 44-48. URL: https://ejournal.upi.edu/index.php/WPF/article/view/8277/0

Setiawan; Adib Rifqi; \& Van Bee, Jeffa Lianto. (2019, October 01). Sekilas tentang Etnomatematika. ResearchGate.net. URL:

https://www.researchgate.net/publication/336206880_Sekilas_tentang_Etnomatem atika

Siayah, Syarofis; \& Setiawan, A.R.. (2019, June 26). Multiple Intelligences Survey: Analysis on Validity and Reliability of Bahasa Indonesia Version Through Different Education Level.

Siayah, Syarofis; Kurniawati, Novi Khoirunnisa; \& Setiawan, A.R.. (2020, February 29). Six Main Principles for Quality Learning based on "Ta'līm al-Muta'allim Ṭorīq alTa'allum". ResearchGate.net. DOI:

https://dx.doi.org/10.13140/RG.2.2.32361.65127

Siayah, Syarofis; Kurniawati, Novi Khoirunnisa; Velasufah, Whasfi; Setiawan, A.R.. (2019, September 30). A Brief Explanation of Basic Science Education.

ResearchGate.net. URL:

https://www.researchgate.net/publication/339385375_A_Brief_Explanation_of_Basic _Science_Education

Velasufah, Whasfi; \& Setiawan, A.R.. (2019, August 09). Science Motivation Questionnaire II (SMQ-II): Analysis on Validity and Reliability of Bahasa Indonesia Version Through Various Learning Context. 